\title{
Ambiguity, Uncertainty and Implementation
}

Kristin Taylor, Stephanie Zarb and Nathan Jeschke

\section{(2) OpenEdition}

\section{Journals}

Electronic version

URL: https://journals.openedition.org/irpp/1638

DOI: $10.4000 /$ irpp. 1638

ISSN: 2706-6274

\section{Publisher}

International Public Policy Association

Printed version

Date of publication: 15 March 2021

ISSN: 2679-3873

\section{Electronic reference}

Kristin Taylor, Stephanie Zarb and Nathan Jeschke, "Ambiguity, Uncertainty and Implementation", International Review of Public Policy [Online], 3:1 | 2021, Online since 15 March 2021, connection on 17 June 2021. URL: http://journals.openedition.org/irpp/1638 ; DOI: https://doi.org/10.4000/irpp.1638

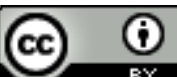

International Review of Public Policy is licensed under a Creative Commons Attribution 4.0 International. 


\section{Ambiguity, Uncertainty and Implementation}

\section{Kristin Taylor}

Associate Professor, Department of Political Science, Wayne State University, USA

\section{Stephanie Zarb}

Ph.D. Candidate, Department of Political Science, Wayne State University, USA

\section{Nathan Jeschke}

Doctoral Student, School of Public Affairs, University of Colorado Denver, USA

\section{Abstract}

In policy implementation the roles of ambiguity and uncertainty have been theorized but insufficiently tested. This study contributes to the policy process literature by arguing that ambiguity and uncertainty are two sides of the same coin in implementation. Their effects are linked to the credibility of policy, the clarity of goals, and agency capacity. We analyze ambiguity and uncertainty through the lens of post-disaster policy in local government using primary qualitative data from 22 local government officials across 8 counties and 6 cities that were affected by Hurricane Harvey. We find that the credibility of a policy is evaluated separately from the credibility of the formulator; experience moderates the effects of ambiguity; and uncertainty in implementation has a similar effect as ambiguity and is not lessened with more information. The distinction between the political manipulation of ambiguous circumstances and the rational, technocratic approach to gathering more information to reduce uncertainty may be less clear than previously considered.

\section{Keywords}

policy implementation, ambiguity, uncertainty, local government, disaster, Multiple Streams Framework 


\section{Introduction}

A fundamental challenge in advancing knowledge of the policy process is understanding the apparent gap between how policy is formulated and implemented (Baier et al., 1986; Matland, 1995; O'Toole, 1995; Pressman \& Wildavsky, 1973). There are two common explanations: the first is that ambiguity in formulation allows for political deal making to pave the way for policy change (Herweg et al., 2018); the second is that understanding technical and scientific information in the policy process creates uncertainty that actors must contend with when weighing policy options (Jenkins-Smith et al., 2014; Weible et al., 2009). The extent to which policy actors can manage ambiguity and uncertainty contributes to learning about which policy tools to implement after a failure (Howlett, Ramesh \& Wu 2015; May 1992), particularly after a disaster (Albright \& Crow 2019; Birkland 1997; Crow \& Albright 2019; Sapat et al. 2011).

The objective of this study is to examine the role of ambiguity and uncertainty in policy implementation. On one hand, policy implementers face uncertainty, or having to make decisions in the face of limited information (Jones \& Baumgartner, 2012). Uncertainty is resolved with more information or better use of existing information, allowing for boundedly rational, technocratic decision-making. On the other hand, ambiguity, or that idea that policy makers will have different ways of understanding policy problems (Herweg et al., 2018; Zahariadis, 2008), is resolved by political activity that allows for different interpretations of the policy problem (Cairney, 2019). We conceive of ambiguity and uncertainty as cross-cutting concepts in the Multiple Streams Framework (Herweg et al., 2018), the Advocacy Coalition Framework (Jenkins-Smith, Nohrsted, \& Weible Sabatier 2014), Punctuated Equilibrium Theory (Jones \& Baumgartner, 2012), and policy learning (Dunlop \& Radaelli, 2018).

The analysis relies on data collected from open-ended interviews with 22 local government officials in 14 cities and counties in Texas that were implementing hurricane and flood hazard mitigation policies after Hurricane Harvey. We find that implementation is influenced by ambiguity, but experience with the policy may moderate their effects. We also find that uncertainty is not always lessened by more information, therefore rendering its influence to be more similar to ambiguity than previously conceived.

\section{A Framework for Understanding Ambiguity and Uncertainty in Implementation: Credibility and Clarity}

We introduce a theoretical framework grounded in the policy implementation literature focused on evaluating the impact of ambiguity and uncertainty as barriers to policy implementation (Fowler, 2020; Goggin et al., 1990; Manna \& Moffitt, 2019; Matland, 1995; O’Toole, 1995; Zahariadis, 2008). By operationalizing key concepts of ambiguity and uncertainty, we can unpack the influence of each of these concepts on policy implementation within a nested system of government. Broadly speaking, ambiguity refers to the idea that there are multiple ways to interpret policies (Zahariadis, 2008), and uncertainty refers to the idea that policy implementers may not understand those policies (Jones \& Baumgartner, 2012). In this study, we examine implementation in the U.S. federal system of government. This means that policy implementation occurs within a nested system of federal, state, and local levels where local policy makers face significant challenges in implementing policies designed by federal and state agencies.

The literature makes a clear distinction between ambiguity, which cannot be lessened with more information, and uncertainty, which can be resolved with more information (Cairney, 2019). We use the frame of policy credibility in implementation to articulate the dynamics 
of ambiguity. Uncertainty is examined in terms of the clarity of policy goals and capacity of municipal governments to implement mitigation and recovery policies. The central theory of this study is that the credibility of policymakers, the clarity of policy goals, and capacity of implementers are important influences on decisions made during implementation.

\section{Ambiguity, Credibility and Package Deals}

In order to implement a policy, local decision makers must come to a consensus on what the policy problem is and which policy tools to use to solve it. Ambiguity refers to the idea that because there are many ways to understand a policy problem (Cairney, 2019), the goals of a proposed policy, and the means to achieve the desired goals (Matland, 1995), it is difficult for officials to come to a consensus. Thus, political gamesmanship develops between policy implementers competing to push forward their preferred problem definitions and policy solutions. Policy implementers may not have the time or ability to gather and analyze all available information and will likely rely on sources they trust and adapt information to beliefs and biases they already hold (Cairney, 2019).

The literature suggests there is a clear relationship between the perceived credibility of the institutions which create a policy, the messages they send, and the willingness of local government officials to implement said policy. The communications model of intergovernmental implementation asserts that messages sent by authoritative senders to willing receivers will be more quickly and faithfully acted upon than less credible messages sent to unwilling receivers (Goggin et al., 1990). The concern for how bureaucratic discretion is used is whether the messages being sent from top-level government agencies are perceived as credible, whether the sender is considered authoritative, and whether local governments are willing to act upon the information. In this model, state governments are often in the role of intermediaries and interpreters between national and local governments (Hill \& Hupe, 2002).

For the use of bureaucratic discretion in the context of policy implementation, two important questions are: (1) whether the messages received from the federal government are perceived to be credible, and; (2) the extent to which those messages are considered to be authoritative as they are sent from federal to state to local officials responsible for hazards and disasters. The relative authoritativeness of the federal government with respect to mitigation has been uneven. For example, federal incentives to mitigate have been relatively ineffective at influencing local planning for disasters (Berke et al., 2014).

Operationalizing and identifying credibility can be a challenge because it is based on the perception of the policy by an implementer (May \& Jochim, 2013). Political commitment is an important signal for the credibility of a policy (Liu et al., 2018). In a nested governance system, where the local implementing government is on the receiving end of policies that have already been formulated, perceived credibility becomes even more complicated. We distinguish between the credibility of the agency sending the policy message and the credibility of the policy that agency is sending the message about. Decoupling the credibility of the agency and the credibility of the policy allows for the possibility that a credible actor may encourage implementation of a policy that lacks credibility, or an actor that lacks credibility might encourage implementation of a policy that is credible.

Thus, this study poses the following:

Proposition 1: Policies are less likely to be implemented when the credibility of the actors who formulated the policy is low. 
We expect that implementation of various policy tools in the post-disaster environment will be affected by ambiguity. For policy implementation after a disaster in a nested system of government, we expect that where the policy is mostly transactional and administrative - for example disbursing personal assistance to persons adversely affected by the disaster - there will be low ambiguity. In contrast, where the policy is less transactional - for example when changing building codes - ambiguity about the policy's goals will remain low but the political conflict will be high because changing the building codes, thus increasing cost of construction, is highly contested (Albright \& Crow, 2015; O'Donovan, 2017b). Through the lens of ambiguity and conflict (Matland, 1995), we would expect to see outcomes determined by resources in transactional and administrative policy areas and outcomes determined by political power in less transactional policy areas.

The idea of political compromise and package deals that happen at the highest policy making levels during formulation can undermine the credibility of a policy in the eyes of the local actors in agencies responsible for implementation (Zahariadis, 2008). This is particularly true when implementation happens in a nested system of government, where the strategies and tactics used in policy formulation happen without the inclusion of the local policy makers responsible for policy implementation. Policies which are a part of a package of policy programs are likely to be the result of political deal making, gamesmanship and manipulation of the policy problem, and are thus likely be more ambiguous. Thus, this study proposes the following:

Proposition 2: Policies are less likely to be implemented when they are part of a package of policy programs.

\section{Uncertainty, Clarity, and Capacity}

Understanding the differences between the stated intention of a policy and its outcome is an important problem of policy implementation (Ferman, 1990; Mazmanian \& Sabatier, 1983; O'Toole, 1995). The literature suggests that all interested staff and agencies might agree on what the end result of the policy should be but they do not necessarily agree on how to get there (Pressman \& Wildavsky, 1973).

Evidence-based policy making (EBPM) suggests that while policy makers may have limited time and attention to deal with problems, they are goal oriented and desire to get decisions "right." The EBPM model predicts that policy makers desire to seek out evidence to determine the best possible solutions (Cairney, 2019); where policy goals are clear and messages sent regarding the policies are easily interpreted, implementation is more likely. Thus, the clarity of a policy in implementation is critical. In the US context, policy implementation can often take place in a nested system where a great deal of responsibility rests with state and local governments.

For example, the role that states play is important because planning mandates, particularly for land use and hazard mitigation, are influential on the capacity and quality of local land use plans (Berke et al., 2014). This is because the federal government shares most resources and creates obligations for states in many cases. State governments are therefore in the middle of the communications chain between the top-level policy designers and local implementers. Crucially, "state level implementers form the nexus for the communication channels and these implementers are the target of the implementation-related messages transmitted from both federal and local level senders" (Lester \& Goggin, 1998). Indeed, when the policy standards and expectations about enforcement are confusing, implementation may be undermined (Liu et al., 2018). 
When the federal government sends implementation messages that are considered unclear, states play an important role in sending more authoritative messages to local governments that implementation is important. When the federal government sends messages about policy preferences to states, the messages can be distorted, either intentionally or unintentionally (Van Meter \& Van Horn, 1975). As recipients, "state level implementers must interpret a barrage of messages. Structuring the interpretation process are the form and content of the messages and the legitimacy and reputation of the sender. Therein lies the key to implementation's variability" (Lester \& Goggin, 1998).

The clarity of a policy output is potentially related to the clarity of the information about the policy goals. Therefore:

Proposition 3: Policies are more likely to be implemented when policy makers send clear messages about the goals of a policy.

Finally, the capacity of government is important for implementation. We define capacity as the ability of a local government to reduce uncertainty about policy tools. There is a significant body of literature that indicates that mid-level government managers are important for creating the conditions under which ground-level implementers can interpret a policy in a way that is consistent with its stated goals (Cloutier et al., 2016; Hupe, 2011; May \& Winter, 2009; Meier \& O’Toole, 2002; Ricucci, 2005).

We conceive of capacity as the ability of boundedly rational decision makers in local government (Jones, 2003; Simon, 1991)to make a policy choice after disaster. That ability to make a choice is bounded by cognitive ability and governing capacity to interpret policy goals. Municipalities play an important role in translating national policy goals. The extent to which municipal managers emphasize national goals facilitates consistency in street-level bureaucrats implementing policies that are consistent with the national goals (May \& Winter, 2007). If there is uncertainty at the local level about the goals of a policy, its successful implementation is less likely (Goggin et al., 1990), thus:

Proposition 4: Policies are less likely to be implemented when policy implementers are unable to interpret the goals of a policy.

\section{Case, Methodology and Data}

This study uses primary qualitative data on local government decision making after Hurricane Harvey. A qualitative approach is appropriate for this study because our objective is to identify the characteristics of ambiguity and uncertainty, rather than predict the effects of them. Hurricane Harvey was selected as the case because of its severity, scope, and impact on varying communities across a wide region of the State of Texas. Hurricane Harvey made landfall near Rockport, Texas, on August 26, 2017, as a Category 4 storm. Harvey affected 32 counties in Southeast Texas, warranting a Presidential Disaster Declaration (Chokshi \& Astor 2017). Although the damage was widespread, the severity of the Hurricane varied significantly from one community to another. For example, the city of Houston experienced Harvey as a significant rain event, causing urban surface flooding. But communities along the Coastal Bend region experienced the effects of Hurricane as a wind event and the Gulf Coast region of Texas experienced Harvey as a flooding event. It ties with Hurricane Katrina as the costliest hurricane in United States history (Blake \& Zelinsky 2018). Cities and counties were selected to account for varying impact of the hurricane-major cities like Houston felt the effects of the disaster, as did rural counties with no major cities, like Brazoria County. 
Using an open-ended interview questionnaire that was guided by the literature, we conducted 15 open-ended interviews with 22 local government officials across 8 counties and 6 cities impacted by Hurricane Harvey in August 2018 and March 2019. The interview subjects were selected because we identified them to be key decision makers in their communities about post-disaster policy implementation. The interview subjects included county judges (an elected position in the State of Texas that functions like a county executive), emergency managers, community planners, mitigation specialists, floodplain managers, city managers, and longterm recovery specialists. A codebook was developed to conduct a content analysis of the interview transcripts and we conducted a preliminary analysis of a cross-section of the interviews to pilot test the codebook. Some terms were refined, and additional codes were included to clarify for evidence of credibility, communications, and capacity prior to and after Hurricane Harvey. The interview transcripts were analyzed in QDA Miner, a computer assisted qualitative data analysis package (CAQDAS) created by Provalis Research.

Each interview was coded separately by two independent coders. The key variables of interest for this paper are included in Appendix A. After the interviews were coded, intercoder reliability was checked. Intercoder reliability was $70.8 \%$ for frequency of codes per case, $16.4 \%$ for presence or absence per case, and $69.4 \%$ for agreement by code importance. Discrepancies were resolved by agreement between independent coders. Frequency counts were then conducted of the coded segments of each interview. These frequency counts were then used in the analysis and cross-tabulation. In some charts, the frequency counts were transformed into categorical variables. For example, to determine whether the speaker saw FEMA as credible, not credible, or neutral, the total number of mentions of FEMA was analyzed. If the majority of the mentions were "not credible", then the interview was coded as "FEMA not credible"; if a clear majority of mentions were "credible", the interview was coded as "FEMA credible", if there was no clear majority, or if the majority of mentions were coded as "neutral", the overall interview was coded as "FEMA neutral." For some variables, neutral and not frustrated were merged into a single category.

Secondary data measuring demographic and political characteristics was also included in this study. The demographic data is from the U.S. Census Bureau. The 2016 voting data was pulled from the M.I.T Election Data Science Lab in the U.S. President Precinct-Level Returns 2016 database (MIT Election Data and Science Lab, 2018). For the municipalities, their individual precinct maps were projected onto a map displaying municipal boundaries to create a list of included precincts for each municipality. If any part of a precinct was inside the municipal boundary, the votes from the entire precinct were included. For community government expenditures and revenue, each community's budget was downloaded from their website. The revenue collected was expected revenue for FY 2018 in the general fund only; no special sources of revenue were included. The number of major disaster declarations per community was obtained from the FEMA (Federal Emergency Management Agency, n.d.).

Table 1: Community Characteristics Communities in the Study Area

\begin{tabular}{|c|c|c|c|c|c|c|c|c|c|c|c|}
\hline Community & $\begin{array}{l}\text { Total Revenue } \\
\text { (General Fund) }\end{array}$ & $\begin{array}{l}\text { Total } \\
\text { Expenditures }\end{array}$ & $\begin{array}{l}\text { Number of } \\
\text { Full Time } \\
\text { Employees }\end{array}$ & $\begin{array}{l}\text { Trump } \\
\text { Vote } \\
\text { Share }\end{array}$ & $\begin{array}{l}\text { Clinton } \\
\text { Vote } \\
\text { Share }\end{array}$ & $\begin{array}{l}\text { Total Votes } \\
\text { Cast (2016 } \\
\text { Presidential } \\
\text { Election) }\end{array}$ & Population & $\begin{array}{l}\text { Percent } \\
\text { African } \\
\text { American }\end{array}$ & $\begin{array}{l}\text { Percent } \\
\text { Hispanic or } \\
\text { Latino }\end{array}$ & $\begin{array}{l}\text { Median } \\
\text { Income }\end{array}$ & $\begin{array}{l}\text { Major } \\
\text { Disaster } \\
\text { Declarations } \\
\text { (1997-2017) }\end{array}$ \\
\hline Rockport & $\$ 9,901,318$ & $\$ 9,875,617$ & 119 & 72.3 & 25.0 & 7,562 & 10,555 & $3.0 \%$ & $25.4 \%$ & $\$ 59,549$ & 14 \\
\hline Aranasas County & $\$ 15,919,946$ & $\$ 16,617,114$ & 500 & 73.9 & 23.5 & 10,484 & 23,158 & $1.6 \%$ & $27.0 \%$ & $\$ 44,601$ & 14 \\
\hline Brazoria County & $\$ 15,919,946$ & $\$ 16,617,114$ & 500 & 60.4 & 35.8 & 121,181 & 313,166 & $14.1 \%$ & $29.7 \%$ & $\$ 76,426$ & 18 \\
\hline Fort Bend County & $\$ 271,645,456$ & $\$ 278,343,321$ & 2525 & 45.0 & 51.6 & 262,066 & 585,375 & $21.6 \%$ & $24.2 \%$ & $\$ 93,645$ & 15 \\
\hline Belleaire & $\$ 20,316,640$ & $\$ 20,798,898$ & 183.5 & 46.1 & 53.9 & 9,429 & 18,797 & $1.8 \%$ & $8.0 \%$ & $\$ 195,018$ & 18 \\
\hline Harris County & $\$ 2,104,966,396$ & $\$ 1,988,494,090$ & 17362 & 41.8 & 54.2 & $1,312,112$ & $4,092,459$ & $18.9 \%$ & $42.2 \%$ & $\$ 57,791$ & 18 \\
\hline Beaumont & $\$ 125,280,700$ & $\$ 126,717,700$ & 1293 & 18.9 & 79.2 & 1,753 & 118,296 & $48.2 \%$ & $14.8 \%$ & $\$ 45,268$ & 13 \\
\hline Jefferson County & $\$ 119,007,589$ & $\$ 131,744,288$ & 1008 & 49.0 & 48.5 & 87,618 & 252,273 & $34.0 \%$ & $19.5 \%$ & $\$ 46,315$ & 13 \\
\hline Corpus Christi & $\$ 904,187,978$ & $\$ 929,084,949$ & 3160 & 52.9 & 43.3 & 4,914 & 325,733 & $4.1 \%$ & $62.4 \%$ & $\$ 53,626$ & 18 \\
\hline Aransas Pass & $\$ 9,477,991$ & $\$ 8,437,647$ & 102 & 69.4 & 27.4 & 3,802 & 8,960 & $3.2 \%$ & $49.0 \%$ & $\$ 38,852$ & 14 \\
\hline Galveston City & $\$ 127,186,455$ & $\$ 144,586,041$ & 880 & 42.0 & 53.7 & 18,096 & 49,706 & $20.8 \%$ & $28.0 \%$ & $\$ 42,486$ & 15 \\
\hline
\end{tabular}

Source: Compiled by authors 


\section{Analysis and Discussion}

We present the analysis of the qualitative data and examine the results on themes of ambiguity and uncertainty. First, we begin by examining ambiguity in implementation in two ways: (1) the credibility of the policy and the agency; and; (2) the credibility of a package of policies. Then, we assess uncertainty in implementation through the lenses of the clarity of policy goals and local interpretation of policy goals.

\section{Policy and Agency Credibility}

The perceived credibility of federal and state actors by local government decision makers was an important element for policy implementation following Hurricane Harvey. Based on the frequency analysis of the interview transcripts, Table 2 demonstrates that FEMA was perceived as not being credible (22 mentions of not credible versus 9 mentions of credible) while agencies in the State of Texas were viewed as credible or neutral. This distinction is important because FEMA, as the federal agency that formulates most national policies for mitigation, is often the source of policy guidance, technical support and funding for local governments to implement disaster mitigation policies. If local governments do not perceive FEMA to be credible, it implies that local governments would be unlikely to implement mitigation policies, secure funding through FEMA's grants program, or seek out technical assistance to improve capacity. The US Army Corps of Engineers and the Texas Department of Emergency Management were both perceived as being credible actors. Other agencies were mostly neutral, including US Housing and Urban Development, US Small Business Administration, Texas General Land Office, Texas Department of Transportation, and various NGOs. This is important because FEMA's credibility amongst communities which have experienced fewer disasters is low, while the state agencies continue to be viewed as credible.

Table 2: Frequency of mentions of credibility for federal, state, and local agencies

\begin{tabular}{|c|c|c|c|c|c|}
\hline & & & \multicolumn{3}{|c|}{ Credibility of Agencies } \\
\hline & \multicolumn{2}{|c|}{$\begin{array}{l}\text { Direct Evidence of } \\
\text { Credibility }\end{array}$} & \multicolumn{3}{|c|}{$\begin{array}{c}\text { Indirect Evidence of } \\
\text { Credibility }\end{array}$} \\
\hline & Credible & $\begin{array}{c}\text { Not } \\
\text { Credible }\end{array}$ & Negative & Neutral & Positive \\
\hline Federal Agencies & & & & & \\
\hline FEMA & 9 & 22 & 9 & 22 & 1 \\
\hline US Army Corps of Engineers & 6 & 1 & 5 & 4 & 2 \\
\hline US Housing and Urban Development & - & - & - & 2 & - \\
\hline US Small Business Administration & - & - & - & - & 1 \\
\hline State Agencies & & & & & \\
\hline Texas Department of Emergency & 5 & 0 & - & 6 & 2 \\
\hline Management & & & & & \\
\hline Texas General Land Office & - & - & 2 & 1 & 1 \\
\hline Texas Department of Transportation & - & - & - & 1 & - \\
\hline State Agency, Other & - & 1 & 3 & - & - \\
\hline $\begin{array}{r}\text { Non-Governmental Agencies and } \\
\text { Universities }\end{array}$ & 5 & 0 & - & 1 & 2 \\
\hline
\end{tabular}

\section{Source: The Authors}

Proposition 1 stated that policies are unlikely to be implemented when the credibility of the actors who formulated the policy is low. This follows the finding of Lester and Goggin (1998) that the key to variability in implementation is based on the "legitimacy and reputation of the sender" as well as the "willingness of the receiver." To further examine whether local governments who perceive FEMA as lacking credibility would decide to implement a federal policy at all or decide to implement it incompletely (Lester \& Goggin, 1998) we analyzed the relationship 
between perceived agency credibility and policy credibility. Several communities which found FEMA to be not credible still implemented several FEMA polices. Consequently, we examined the perceived credibility of various FEMA policies to determine the impact of the credibility of the sender (FEMA) on the willingness of the local policy implementers to enact various FEMA policies.

In terms of the credibility of the policies themselves, the analysis demonstrates that many of the policies to mitigate and recover from Hurricane Harvey that were available to local governments for implementation were viewed as credible. Table 3 shows that land acquisition and relocation, revised building codes, Community Development Block Grants (CDBGs), drainage projects, base flood elevation modifications, and Hazard Mitigation Grants (HMGs) were viewed as credible.

Table 3: Perceived Credibility of Individual Policies and Programs

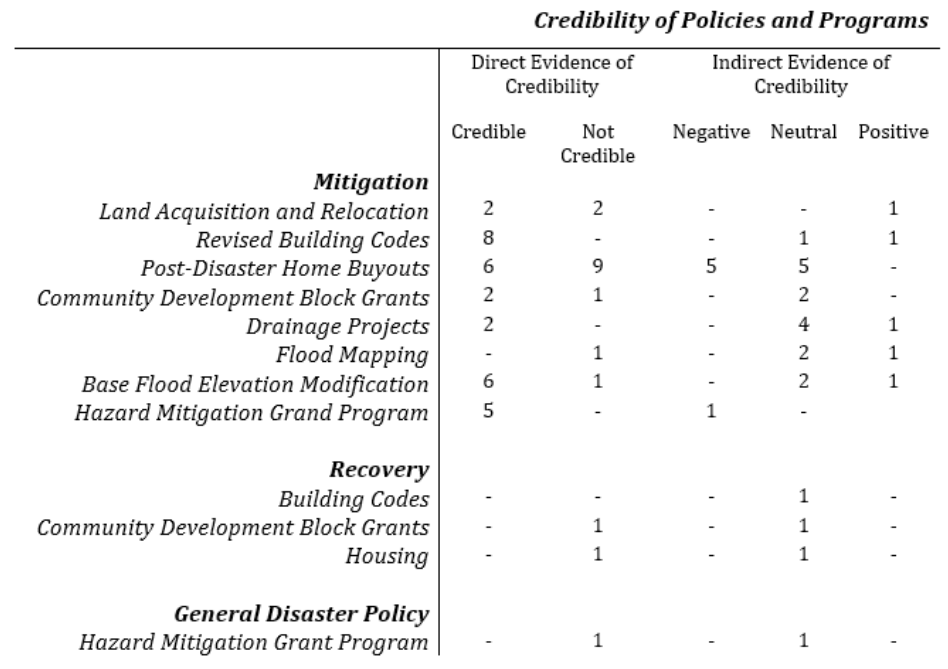

\section{Source: The Authors}

One theme that emerged in several of the interviews was that FEMA's grant programs, which allowed municipalities to apply for federal funds to offset the cost of purchasing homes in the flood plain, were perceived as not credible. For the Post Disaster Buyout Program ${ }^{1}$ the most frequently cited reasoning for buyouts being less credible was loss of the property tax base. One respondent stated:

Once you buyout once, you won't do it again. I've not seen another county do it. It's too much of a tax burden on the county. In Bevil Oaks, for example, if you buyout a property and the next-door neighbor doesn't buyout that neighbor complains if you don't do the maintenance. Buyouts also reduce the tax base. In Port Arthur, you can't buyout or you lose your tax base. We bought out after Ike. The problem is that we ended up owning the properties and you can't do anything with them. You lose the tax base. Without one doubt that drove the decision-making. Plus, we have to cut

\footnotetext{
2 - There are several different FEMA grants which allow municipalities to purchase and remove homes from the flood plain at full pre-disaster value. The majority of post-Harvey buyouts would have been done using Post-Disaster Hazard Mitigation Grants. In this paper we use the generic term "Post Disaster Buyout Program" to refer to homes purchased with Hazard Mitigation Grant money released after a natural disaster.
} 
grass. We spend millions of dollars per year cutting grass on properties we can't do anything with. No one wants a park there. In Texas, property rights are a big deal. Eminent domain lets us do it, but no one in TX believes in it. You are talking about property that's been in families in generations - you can't take it.

The programs themselves tended to be evaluated independently of the local policy maker's opinion of the federal organization. This observation is supported by the fact that a community's overall impression of whether FEMA was credible did not impact their belief in the credibility of FEMA's guidelines for base flood elevation/building codes. In fact, those who found FEMA to be "not credible" were slightly more likely to find building codes/freeboard/base flood elevation standards credible. For the Post Disaster Buyout Program, communities which found the Post Disaster Buyout Program credible were more likely to find FEMA credible. As shown in Figures 1, 2, and 3, a community's perspective on the credibility of the Post Disaster Buyout Program did not appear to be related to their view of the credibility of the FEMA standards pertaining to building codes/freeboard/base flood elevation.

Figure 1: Perceived credibility of FEMA and the Post Disaster Buyout Program

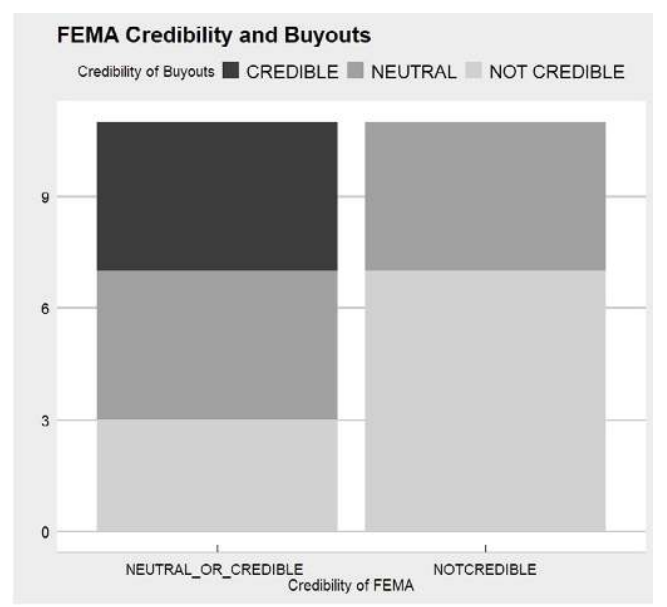

Source: The Authors

Figure 2: Perceived credibility of FEMA and building codes/enforcement of base flood elevation/freeboard requirements

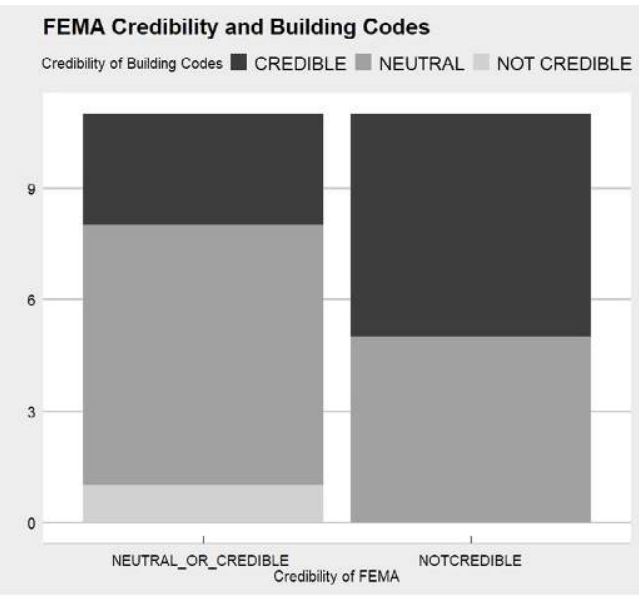


Figure 3: Perceived credibly of the Post Disaster Buyout Program and perceived credibility of restrictive building codes/enforcement of base flood elevation/freeboard requirements

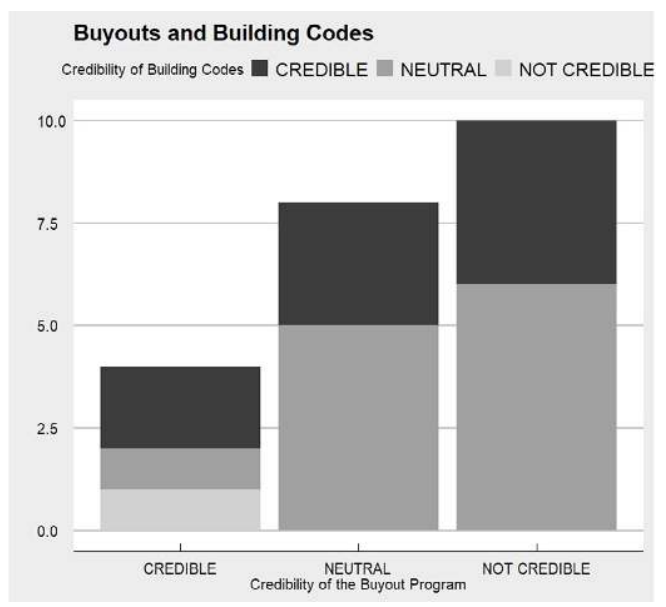

Source: The Authors

To better understand the influence of disasters on implementation, we conceive of them as focusing events (Birkland, 1997), and the accumulation of experience with disasters over time can lead to policy change (O’Donovan, 2017a). Experience with hurricanes appears to be a crucial factor in the communities' perceived credibility of FEMA. The more major disaster declarations a community experienced, the more likely they were to view FEMA as credible. The crosstab analysis of the number of major disaster declarations a community had experienced between 1997-2017 and their perceived credibility of FEMA revealed that among the communities which had experienced a higher number of disasters, $62 \%$ found FEMA credible or were neutral, compared to just $38 \%$ which found FEMA not credible. For those communities which experienced a lower number of major disaster declarations related to flooding, $67 \%$ found FEMA not credible, whereas $33 \%$ were neutral or found FEMA to be credible.

Table 4: Number of Focusing Events by Perceived Credibility of FEMA

Number of Focusing Events and Perceived FEMA Credibility

\begin{tabular}{r|cc} 
& \multicolumn{2}{|c}{ Number of Focusing } \\
Events \\
Perceived FEMA Credibility & Several & Some \\
& $(\geq 15)$ & $(<15)$ \\
FEMA Credible or Neutral & $62 \%$ & $38 \%$ \\
FEMA Not Credible & $33 \%$ & $67 \%$
\end{tabular}

\section{Source: The Authors}

The Post Disaster Buyout Program can be characterized as a policy where ambiguity is low. Local policy officials understood the buyout mechanism and the resources required to implement the Post Disaster Buyout Program. For those policy makers which found the Post Disaster Buyout Program to be less credible, they often cited the loss of the property tax base and the increased maintenance costs associated with the program. This is consistent with what was observed regarding the buyout program in Texas; where powerful policy makers favored the program, buyouts occurred, and where powerful policy makers opposed the program, it was not implemented. 
Another policy with low ambiguity is implementing more stringent building codes, including higher standards for base flood elevation and freeboard. However, policy maker's expressed concern about the rising cost of construction and political push back regarding increased building standards. One theme that quickly emerged was that most of the political pushback, both from policy makers and the general public, subsided after experiencing a flooding event firsthand and observing that those buildings built to a higher standard had a much higher survival rate. This is consistent with our earlier observation that communities which encountered more disasters were more likely to perceive FEMA as credible.

Drawing on the work of Lester and Goggin (1998), Proposition 1 stated that policies are unlikely to be implemented when the credibility of the actors who formulated the policy is low. While we did find support for Proposition 1, we found that the relationship between credibility, policy, and policy implementation is multifaceted. Some communities which did not find FEMA credible still found certain FEMA policies credible, and went forward with the plan to implement them. Additionally, communities with more experience tended to find FEMA more credible. Thus, the relationship between credibly and policy implementation varied based on three important dimensions: the credibility of (1) the agency that formulated the policy; (2) the specific policy tool itself; and (3) the experience level of local government policy makers.

\section{Credibility and Policy Packages}

Certain policy tools to mitigate the effects of hurricanes are stand-alone policies, like building code changes and base flood elevation modifications. They are not part of a larger package of policies, in contrast to the Community Development Block Grant-Disaster Recovery program (CDBG-DR), which provides funding for recovery that includes support for mitigation, housing, and other post-disaster recovery efforts that prioritize low-income communities.

For stand-alone policies, the goals are clear, the objectives are discrete, and their impact is readily observable. For example, several communities have cited that the reason they believe in these standards is because they could observe, first-hand, how properties built to the new standards faired during Harvey. As one respondent noted:

I have a great photo from May 16th when we had a flood. Its aerial from a drone.

There is a Mexican food restaurant built to new codes, and it's high and dry surrounded by water. It told the story.

In contrast, the CDBG-DR is a major deferral policy that is designed as part of a so- called "package deal" for post-disaster mitigation and long-term recovery, the CDBG-DR program, run through the US Department of Housing and Urban Development. These CDBG grants are large grants of federal aid to rebuild or restore housing, assist with community development and mitigate the future effects of disasters. CDBG grants come with significant funding but are accompanied by many rules and requirements that local governments may perceive as not meeting local standards.

The CDBG grants were mentioned in interviews, but the analysis does not demonstrate the phenomenon of package deals as being nearly as problematic as the literature indicates that they should be. CDBG-DR block grants were mentioned in 5 interviews, but their credibility was only discussed in 3 interviews, and in only 1 did the interview subject perceived them to be credible. We did find support for this phenomenon in that the CDBG-DR grants were policies with very high ambiguity. Where political will to implement CDBGs was high, policy makers and grass roots coalitions combined to garner support. The one community where political support was high stated the following: 
I'm proud of our commissioners. They are dedicated to using the Community Development Block Grant for its purpose, for low-moderate income areas and not for costsharing with other grant programs. Using for cost-share is not using the CDBG's how they are intended, and cannibalizes that money. We have a 2.5-million-dollar bond going on the ballot to help us make sure CDBG money stays where it needs to go. We will use federal money to cost share.

However, in the other 2 interviews that mentioned CDBG-DR and thought it lacked credibility, they either perceived that it was a federal cram-down or they felt the requirements were inappropriate for their local context. For example, a comment from one participant with themes about package deals with CDBG block grants was:

Storms don't discriminate based on income, I get why it's need based, but you can have money that you can spend in a non-low-moderate census track, a pond that benefits a low-moderate track, and it won't be eligible. That means with regards to infrastructure funding, you may not be able to place the money where it can do the most good for the most people.

Thus, we accept that we have mixed and weak findings for Proposition 2 and can neither accept nor reject the theory that policies are unlikely to be implemented when they are part of a package of policy programs. We did find support for the idea that stand alone polices are easier to implement.

\section{Clarity of Policy Goals}

There is still a gap between the way federal policies are designed to work and the way that local policy makers understand how these policies are supposed to be implemented. As Table 5 demonstrates, local policy makers felt the federal communication of information and of policy goals were unclear.

Table 5: Local government perception of the clarity of information and messages sent by federal and state government agencies.

\begin{tabular}{r|rr} 
Clarity of Messages Sent by Federal and State Agencies as \\
\multicolumn{3}{|c|}{ Perceived by Local Government } \\
\hline & Clear & Unclear \\
Federal Communication of Information & 6 & 11 \\
State Communication of Information & 3 & 1 \\
Federal Communication of Policy Goals & 3 & 6 \\
State Communication of Policy Goals & 0 & 1
\end{tabular}

\section{Source: The Authors}

State communication was perceived as being clear (3) compared to being explicitly unclear (1). This reinforces the idea that states can play a key role between the federal government and local policy makers. Public statements by TDEM were nearly identical to FEMA, which suggests that clarity of policy messages, like beauty, may be in the eye of the beholder. Federal policy goals were more likely to be unclear (6) than clear (3). State policy goals were viewed as being unclear in one instance and clear in zero instances. This is consistent with what would be expected because federal flood mitigation policy is constructed at the federal level, and therefore state policy goals are unlikely to be a factor. 
The EBPM framework suggests that policy makers intend to make the "right" decisions by seeking out evidence to determine the best policy solutions (Cairney, 2019). However, they are restricted by limited time and attention. In the case of post-flooding policy implementation and consistent with what we found in our interviews, local policy makers desired to obtain grants from FEMA to engage in recovery and mitigation projects. One common theme throughout many interviews was that local officials did not have a solid understanding of FEMA policies or goals. Many respondents expressed frustration and confusion with the intergovernmental implementation process. Despite acknowledging that they had attended FEMA sponsored workshops and received assistance with grant writing, it was clear that many local officials were unable to reduce the uncertainty of the available policy tools.

One important example of this confusion is that local governments had an understanding of disaster mitigation that was distinctly different from their federal and state counterparts. At the local level in several municipalities, local policy makers used the term mitigation to broadly apply to many functions that are academically and federally defined as either preparedness or recovery. As a result, there was a great deal of confusion with local policy makers applying for federal mitigation focused grants to accomplish recovery or preparedness related items. These grants were subsequently fraught with problems, going through multiple rounds of drafts or being ultimately rejected. The literature indicates that uncertainty about technical information should be resolved by more information (Jones, 2003; Simon, 1991), yet despite FEMA pushing information and workshops, local policy makers remained unable to successfully apply for grants, growing frustrated with FEMA in the process.

A common example of this uncertainty about what hazard mitigation is generally and what the goals and activities are that are supported by the HMGP is as follows:

I have one project that they ruled totally ineligible, which is stupid. It's all about the communication; every piece of communication was taken out for six weeks. Do you know under the Hazard Mitigation Program I can't create a fiber optic loop to correct that because it wasn't there before. It's the most asinine thing I've ever seen.

Another example of a local government official expressing frustration about FEMA and trying to obtain hazard mitigation funding after Hurricane Harvey conflates mitigation with recovery and preparedness activities and demonstrates a misunderstanding of what federal mitigation policies can be used to achieve at the local level:

FEMA is terribly slow; we are coming up on 2 years and we don't have a water tower. We lost our water tower in the storm. The water still flows; the water tower creates pressure. We are maintaining water pressure with pumps. It fluctuates. It's hard on our infrastructure. When we started with FEMA, we had an 8-leg water tower, but it sat in the flood plain. We wanted to get a modern single stem storm resistant water tower. We sold it as mitigation for the future. Yay all good. But then they said it's not mitigation, it's improvement [so] we can only put back what you had. We get to the end of that and they changed their mind again. We are getting what we wanted to start with, but it has been frustrating.

In many communities, local policy making officials were frustrated because they failed to understand why their hazard mitigation grants were rejected. Many of these projects were not mitigation projects. An example is grants to "harden critical facilities", install communication equipment, and build shelters. Contrary to what we would expect, the condition of uncertainty persists despite instructions attached to FEMA grants and local municipalities conveying that they attended workshops hosted by FEMA on the grant process. In our analysis, in communi- 
ties whose definition of mitigation did not match FEMA's, 50\% reported being frustrated with FEMA. In communities that understood FEMA's definition of mitigation, only $21 \%$ gave answers indicating they were frustrated with FEMA. Unclear communication of policy preferences from the federal level adversely influenced policy implementation, as indicated in Table 6.

Table 6: Impact of the understanding of FEMA's definition of mitigation and a communities' level of frustration with FEMA

Impact of the understanding of FEMA's definition of mitigation and frustration with FEMA

\begin{tabular}{r|cc}
\hline & \multicolumn{2}{|c}{ Level of Frustration with } \\
& \multicolumn{2}{|c|}{ FEMA } \\
Understanding of FEMA's Definition of Mitigation & Frustrated & Not Frustrated \\
Unclear & $50 \%$ & $50 \%$ \\
Clear & $21 \%$ & $79 \%$
\end{tabular}

\section{Source: The Authors}

Thus, we find there is support for Proposition 3; policies are unlikely to be implemented when policy makers send messages about the goals of a policy that are unclear.

\section{Capacity and Interpretation of Policy Goals}

The EBPM framework states that local decision makers are boundedly rational individuals who strive to make the best decisions possible, while operating under significant time constraints (Jones, 2003; Simon, 1991). It argues that decision makers will attempt to gather evidence to make the best decision possible while recognizing that there are barriers (time and attention) that will prevent optimal decision making (Cairney, 2019). The ability of local officials to make decisions should be influenced by both cognitive ability and governing capacity. Governing capacity is conceived of as an important factor for creating the conditions under which groundlevel implementers can interpret a policy in a way that is consistent with its goals.

Conventionally, we would expect that a lack of understanding about mitigation to be considered uncertainty about technical or scientific information (Jenkins-Smith et al, 2014; Weible et al, 2009). We therefore proposed that municipalities with more governing capacity are likely to be better suited to interpret policy goals. We used the number of full-time equivalent municipal employees and general fund revenue per capita as indicators of governing capacity. We hypothesized that municipal governments with higher rates of employees per capita and revenue per capita would have more resources to invest in interpretation of policy goals. We found that greater governing capacity did not translate to better understanding of the definition of mitigation or less frustration with FEMA.

Many of the post-disaster policies available to local decision makers have distinct goals, either recovery or mitigation related. An important part of implementing those policies is submitting a grant application that details how the local government will reach those recovery or mitigation related goals. We found that in communities where there was uncertainty about the goals of a policy, they were unsuccessful in applying for those grants.

Interestingly, policy makers from municipalities with less general fund revenue per capita and fewer employees per capita were slightly more likely to understand FEMA's definition of mitigation and slightly less likely to be frustrated with FEMA. To further understand this phenomenon, we decided to examine the impact of experience with the policy problem as another 
possible explanation. We operationalized experience with the policy problem as the number of hurricanes for which federal aid was authorized over a 20-year (1997-2017) period. We found that municipalities with more experience responding to hurricanes were far more likely to understand FEMA's definition of mitigation and to be less frustrated with FEMA. We conclude that while we find support for Proposition 4 - that policies are unlikely to be implemented when policy implementers are unable to interpret the goals of the policy - we posit that experience, not governing capacity, is key to municipalities understanding the goals of policies and successfully implementing them. The results are presented in Table 7.

Table 7: Understanding of Mitigation and Frustration with FEMA by Community Characteristics

\begin{tabular}{|c|c|c|c|c|}
\hline & \multicolumn{2}{|c|}{$\begin{array}{l}\text { Definition of Mitigation } \\
\text { Consistent with FEMA }\end{array}$} & \multicolumn{2}{|c|}{ Frustration with FEMA } \\
\hline & Consistent & $\begin{array}{c}\text { Not } \\
\text { Consistent }\end{array}$ & $\begin{array}{l}\text { Not } \\
\text { Frustrated }\end{array}$ & Frustrated \\
\hline \multicolumn{5}{|l|}{$\begin{array}{r}\text { General Fund Revenue per } \\
\text { Capita }\end{array}$} \\
\hline Higher $(>\$ 1000.00)$ & 4 & 4 & 7 & 1 \\
\hline Lower $(\leq 999.99)$ & 10 & 4 & 8 & 6 \\
\hline \multicolumn{5}{|l|}{$\begin{array}{l}\text { Number of Full-Time } \\
\text { Equivalent Municipal } \\
\text { Employees per Capita }\end{array}$} \\
\hline More (>.008) & 5 & 6 & 7 & 4 \\
\hline Fewer $(\leq .007)$ & 9 & 2 & 8 & 3 \\
\hline \multicolumn{5}{|l|}{ Number of Focusing Events } \\
\hline Several $(>15)$ & 11 & 2 & 11 & 2 \\
\hline Some $(\leq 14)$ & 3 & 6 & 4 & 5 \\
\hline
\end{tabular}

Source: The Authors

\section{Uncertainty and Ambiguity}

For Propositions 1, 3, and 4, we find support for the connection between the clarity of the message, the clarity of the goals of the policy, and policy implementation. Most surprisingly, we found evidence of more ambiguity in implementation than we had anticipated. There was ambiguity in how local government officials perceived the federal government's policy goals and preferences for how to mitigate after Hurricane Harvey. But more importantly there was considerable evidence that the amount of experience local government officials had contributed to both their ability to understand federal governmental activities in disaster governance and their ability to navigate ambiguous conditions surrounding policy implementation. 
Successful policy implementation requires reducing both uncertainty and ambiguity, and the literature suggests that where uncertainty can be reduced by more information, ambiguity cannot be reduced because there will always be multiple ways of interpreting situations. In our study, we found overwhelmingly that experience reduced both uncertainty and ambiguity, leading us to conclude that the terms are closer than the literature would suggest, and that experience is key in policy implementation. We find ambiguity and uncertainty to be two sides of the same coin. In our findings training workshops, grant writing assistance, and other programs designed to reduce uncertainty were unsuccessful. This suggests that the distinction between uncertainty and ambiguity may be less clear than the literature suggests, and additional information does not always lessen uncertainty.

\section{Results and Implications}

This study sheds light on the roles of ambiguity and uncertainty in implementation, where ambiguity is related to the credibility of the policy and uncertainty is related to the clarity of the policy. Fundamentally, we find that despite distinctions in the literature that ambiguity lies in political decision making and uncertainty resides in rational decision making, the two concepts effectively pose the same challenges for implementation. Specifically, our findings have three main theoretical and practical implications.

First, we find that local governments evaluate the credibility of policies separately from the credibility of the agency that formulate them. With regards to credibility, we proposed that policies were unlikely to be implemented when the credibility of the actors who formulated the policy was low. While we did find support for this theory, we also discovered that policies appeared to be evaluated for implementation more on their impact on the municipality rather than by the credibility of the agency which authored it. Local governments understand the Post Disaster Buyout Program, but buyouts are considered to not to be credible because of their negative impact on the tax base of local municipalities. In contrast, base flood elevation/freeboard guidelines are seen as more credible because local officials have been able to observe the impact of the new standards firsthand. Thus, a community's overall impression of whether FEMA was credible did not impact their belief in the credibility of FEMA's guidelines for base flood elevation/building codes. In fact, those who found FEMA to be "not credible" were slightly more likely to find building codes/freeboard/base flood elevation standards credible. Communities which found the Post Disaster Buyout Program credible were more likely to find FEMA credible. However, a community's view on the credibility of the Post Disaster Buyout Program did not appear to be related to their view of the credibility of the FEMA standards pertaining to building codes/freeboard/base flood elevation.

Second, we find that ambiguity is conditional in implementation. The ambiguity around the choice of a policy tool to implement after a disaster is moderated by the experience of a local government and its capacity to implement. This finding adds to our understanding of ambiguity in decision making that previously suggested that ambiguity could not be reduced. Ambiguity is more often present and important than we anticipated in local government decision-making about implementation of hazard mitigation policies. The lack of an agreed upon understanding was a crucial point of failure. Communities which had a definition of mitigation which was not consistent with FEMA's were far more likely to report being "extremely frustrated" with FEMA. The term mitigation was defined by FEMA in grant instructions and likely covered in grant workshops. When local policy makers failed to understand how FEMA defines mitigation, they became frustrated with FEMA, not the Hazard Mitigation Grant Process, which they 
still viewed as credible. Another important finding is that communities which had experienced more focusing events were more likely to have an understanding of the term mitigation that was consistent with FEMA's. Thus, it appears that while ambiguity leads to a great deal of frustration throughout policy implementation, experience is an important mitigating factor.

While, broadly speaking, we found experience lessened frustration with FEMA, we also found evidence that experience with a specific policy tool that is being considered for implementation matters. Where policy makers have had the opportunity to observe the efficacy of a policy firsthand (base flood elevation, building codes) they will see it as credible regardless of the credibility of the federal institution (FEMA). Experience also lessened frustration with FEMA, with communities that have experienced more disasters more likely to understand FEMA's definition of mitigation, to find FEMA more credible, and to be less frustrated with FEMA. The implication is that experience with a policy problem acts as a mediating and facilitating factor in implementation.

One important factor to help promote implementation is involvement of state agencies. Overwhelmingly, state institutions and process were viewed as more credible than federal institutions and processes; this reinforces the idea that state governments are important intermediaries between federal and local governments in policy implementation.

Third, we find that uncertainty influences policy implementation in a way that is more similar to ambiguity than previously considered. In many instances, uncertainty was not reduced by more information. This suggests that the effect of uncertainty is similar to ambiguity, supporting our "two sides of the same coin" argument about the concepts and their theoretical and empirical roles. Policy and disaster experience act as a moderating effect on implementation conflict and is associated with policies being perceived as credible. In addition, experience lessens both ambiguity and uncertainty.

In our analysis we observed frequent misunderstandings of what flood mitigation is and the tools available, resulting in confusion about the types of local projects eligible for federal mitigation programs. Conventionally, we would expect that a lack of understanding of mitigation to be considered uncertainty about technical and scientific information (Jenkins-Smith et al., 2014; Weible et al., 2009) that could be resolved with more information (Feldman, 1989; Wilson, 1998). However, we found that uncertainty functioned more like ambiguity in that misunderstandings persisted in spite of both FEMA and local officials reporting frequent, high levels of technical assistance. The implication is that the distinction between the political manipulation of ambiguous circumstances and the rational, technocratic approach to gathering more information to reduce uncertainty may be less clear, theoretically and empirically, than previously considered.

Finally, we failed to find support for the idea that policies which are part of a package of policy programs are less likely to be implemented. This is inconsistent with other findings in the policy literature, particularly the Multiple Streams Framework (Zahariadis, 2008; Zahariadis \& Exadaktylos, 2016). There are three potential explanations: the theory does not withstand empirical testing; our data is insufficient; and the case of Hurricane Harvey is not suitable for testing this piece of the theory. We suspect that packages or policies are indeed problematic and our data hints at this. However, we cannot support this proposition. Furthermore, we are unconvinced that ambiguity is the reason why packages of policies are problematic. We suspect that reluctance to apply federal policy preferences to a local problem might be another explanation. Further study is needed to examine the challenges of untangling the meaning of packages of polices. 
In conclusion, there are two broad implication of this research for the study of policy process and policy implementation. First, for theories of the policy process that make assumptions about ambiguous decision-making circumstances, like the Multiple Streams Framework, or conditions of uncertainty in a policy community, like the Advocacy Coalition Framework, these findings suggest that ambiguity and uncertainty can mediated by experience over time. Furthermore, ambiguity may be lessened by using state agencies, which were viewed by local policy makers as being more credible, to send important messages about policy tools. Somewhat confoundingly, in this study, uncertainty was not lessened with more information. This has important implications for theories of the policy process that emphasize the importance of information, like policy learning and evidence-based policy making. Second, for policy implementation, the findings from this study represent a set of empirical findings that are a step forward for unpacking the politics of implementation in a nested system of government. Understanding how local governments choose which policies to implement seems to hinge in part on capacity. However, future research is necessary to assess the influence of the means, willingness and organizational capacity of government on decision making in policy implementation.

\section{Bibliography}

Albright, E. A., \& Crow, D. A. (2015). Learning processes, public and stakeholder engagement: Analyzing responses to Colorado's extreme flood events of 2013. Urban Climate, 14, 79-93. https://doi.org/10.1016/j.uclim.2015.06.008

Albright, E. A., \& Crow, D. A. (2019). Capacity Building toward Resilience: How Communities Recover, Learn, and Change in the Aftermath of Extreme Events. Policy Studies Journal, psj.12364. https://doi.org/10.1111/psj.12364

Baier, V. E., March, J. G., \& Saetren, H. (1986). Implementation and ambiguity. Scandinavian Journal of Management Studies, 2(3), 197-212.

https://doi.org/10.1016/0281-7527(86)90016-2

Berke, P. R., Lyles, W., \& Smith, G. (2014). Impacts of Federal and State Hazard Mitigation Policies on Local Land Use Policy. Journal of Planning Education and Research, 34(1), 60-76. https://doi.org/10.1177/0739456X13517004

Birkland, T. A. (1997). After disaster: Agenda setting, public policy, and focusing events. Washington, DC: Georgetown University Press.

Cairney, P. (2019). Evidence and policy making. Bristol: Policy Press..

Blake, E. S., \& Zelinsky, D. A. (2018). Tropical Cyclone Report Hurricane Harvey (No. AL092017). NOAA: National Hurricane Center. Retrieved from :

https://www.hsdl.org/?view\&did=807581

Chokshi, N., \& Astor, M. (2017, August 28). Hurricane Harvey: The Devastation and What Comes Next. The New York Times. Retrieved from :

https://www.nytimes.com/2017/08/28/us/hurricane-harvey-texas.html?smid=url-share

Cloutier, C., Denis, J.-L., Langley, A., \& Lamothe, L. (2016). Agency at the Managerial Interface: Public Sector Reform as Institutional Work. Journal of Public Administration Research and Theory, 26(2), 259-276. https://doi.org/10.1093/jopart/muv009 
Crow, D. A., \& Albright, E. A. (2019). Intergovernmental relationships after disaster: State and local government learning during flood recovery in Colorado. Journal of Environmental Policy \& Planning, 21(3), 257-274. https://doi.org/10.1080/1523908X.2019.1623660

Dunlop, C. A., \& Radaelli, C. M. (2018). Does Policy Learning Meet the Standards of an Analytical Framework of the Policy Process?: Policy Learning Framework. Policy Studies Journal, 46, S48-S68. https://doi.org/10.1111/psj.12250

Federal Emergency Management Agency. (n.d.). Disaster Declarations by State/Tribal Government. [U.S. Department of Homeland Secuirty]. Retrieved March 24, 2020, from:

https://www.fema.gov/disasters/state-tribal-government/0/TX\#

Feldman, M. S. (1989). Order without design: Information production and policy making.. Stanford, CA: Stanford University Press.

Ferman, B. (1990). When failure is success: Implementation and Madisonian government. In DJ Palumbo \& DJ Calista (Eds.), Implementation and the Policy Process: Opening up the Black Box(pp.39-50). New York: Greenwood Press.

Fowler, L. (2020). Using the Multiple Streams Framework to Connect Policy Adoption to Implementation. Policy Studies Journal, Wiley Online Library.

https://doi.org/10.1111/psj.12381

Goggin, M. L., Bowman, A. O., Lester, J. P., \& O’Toole, L. J. (1990). Implementation theory and practice: Toward a third generation. Glenview, IL: Scott Foresman \& Co.

Herweg, N., Zahariadis, N., \& Zohlnhöfer, R. (2018). The Multiple Streams Framework: Foundations, refinements, and empirical applications. In C. Weible \& P. Sabatier, Theories of the Policy Process (pp. 17-53).Boulder, CO: Westview Press.

Howlett, M., Ramesh, M., \& Wu, X. (2015). Understanding the persistence of policy failures: The role of politics, governance and uncertainty. Public Policy and Administration, 30(3-4), 209-220. https://doi.org/10.1177/0952076715593139

Hill, M., \& Hupe, P. (2002). Implementing public policy: Governance in theory and in practice. London: Sage.

Hupe, P. L. (2011). The Thesis of Incongruent Implementation: Revisiting Pressman and Wildavsky. Public Policy and Administration, 26(1), 63-80.

https://doi.org/10.1177/0952076710367717

Jenkins-Smith, H., Nohrstedt, D., Weible, C. M., \& Sabatier, P. A. (2014). The Advocacy Coalition Framework: Foundations, Evolution, and Ongoing Research. In C. Weible \& P. Sabatier, Theories of the Policy Process (pp.183-222). Boulder, CO: Westview Press..

Jones, B. D. (2003). Bounded Rationality and Political Science: Lessons from Public Administration and Public Policy. Journal of Public Administration Research and Theory, 13(4), 395-412. https://doi.org/10.1093/jopart/mug028

Jones, B. D, \& Baumgartner, F. R. (2012). From there to here: Punctuated equilibrium to the general punctuation thesis to a theory of government information processing. Policy Studies Journal, 40(1), $1-20$.

Lester, J. P., \& Goggin, M. L. (1998). Back to the future: The rediscovery of implementation studies. Policy Currents, 8(3), 1-9.

Liu, N., Tang, S.-Y., Zhan, X., \& Lo, C. W.-H. (2018). Political Commitment, Policy Ambiguity, and Corporate Environmental Practices. Policy Studies Journal, 46(1), 190-214.

https://doi.org/10.1111/psj.12130 
Manna, P., \& Moffitt, S. L. (2019). Traceable Tasks and Complex Policies: When Politics Matter for Policy Implementation. Policy Studies Journal.

https://doi.org/10.1111/psj.12348

Matland, R. E. (1995). Synthesizing the Implementation Literature: The Ambiguity-Conflict Model of Policy Implementation. Journal of Public Administration Research and Theory, 5(2), 145-174. https://doi.org/10.1093/oxfordjournals.jpart.a037242

May, P. J. (1992). Policy Learning and Failure. Journal of Public Policy, 12(4), 331-354. JSTOR.

May, P. J., \& Jochim, A. E. (2013). Policy Regime Perspectives: Policies, Politics, and Governing. Policy Studies Journal, 41(3), 426-452.

https://doi.org/10.1111/psj.12024

May, P. J., \& Winter, S. C. (2007). Collaborative service arrangements. Public Management Review, 9(4), 479-502.

https://doi.org/10.1080/14719030701726473

May, P. J., \& Winter, S. C. (2009). Politicians, Managers, and Street-Level Bureaucrats: Influences on Policy Implementation. Journal of Public Administration Research and Theory, 19(3), 453-476. https://doi.org/10.1093/jopart/mum030

Mazmanian, D. A., \& Sabatier, P. A. (1983). Implementation and public policy. Glenview, IL: Scott Foresman.

Meier, K. J., \& O’Toole, L. J. (2002). Public management and organizational performance: The effect of managerial quality. Journal of Policy Analysis and Management, 21(4), 629-643. https://doi.org/10.1002/pam.10078

MIT Election Data and Science Lab. (2018). U.S. President Precinct-Level Returns 2016 (MIT Election Data and Science Lab, Ed.; V11 ed.). Harvard Dataverse.

https://doi.org/10.7910/DVN/LYWX3D

O’Donovan, K. (2017a). An Assessment of Aggregate Focusing Events, Disaster Experience, and Policy Change. Risk, Hazards \& Crisis in Public Policy, 8(3), 201-219.

https://doi.org/10.1002/rhc3.12116

O’Donovan, K. (2017b). Policy Failure and Policy Learning: Examining the Conditions of Learning after Disaster. Review of Policy Research, 34(4), 537-558.

https://doi.org/10.1111/ropr.12239

O'Toole, L. J. (1995). Rational Choice and Policy Implementation: Implications for Interorganizational Network Management. The American Review of Public Administration, 25(1), 43-57. https://doi.org/10.1177/027507409502500103

Pressman, J. L., \& Wildavsky, A. B. (1973). How great expectations in Washington are dashed in Oakland. Berkeley, CA University of California.

Ricucci, R. (2005). La generazione" 1.5" di minori stranieri. Strategie di identità e percorsi di integrazione fra famiglie e tempo libero. Polis, 19(2), 233-264.

Sapat, A., Li, Y., Mitchell, C., \& Esnard, A. M. (2011). Policy learning and policy change: Katrina, Ike and post-disaster housing. International journal of mass emergencies and disasters, 29(1).

Simon, H. A. (1991). Bounded Rationality and Organizational Learning. Organization Science, 2(1), 125-134.

https://doi.org/10.1287/orsc.2.1.125 
Van Meter, D. S., \& Van Horn, C. E. (1975). The Policy Implementation Process: A Conceptual Framework. Administration \& Society, 6(4), 445-488.

https://doi.org/10.1177/009539977500600404

Weible, C. M., Sabatier, P. A., \& McQueen, K. (2009). Themes and Variations: Taking Stock of the Advocacy Coalition Framework. Policy Studies Journal, 37(1), 121-140.

https://doi.org/10.1111/j.1541-0072.2008.00299.x

Wilson, J. (1998). Bureaucracy What Government Agencies Do and Why They Do It. New York, NY: Basic Books.

Zahariadis, N. (2008). Ambiguity and choice in European public policy. Journal of European Public Policy, 15(4), 514-530.

Zahariadis, N., \& Exadaktylos, T. (2016). Policies that succeed and programs that fail: Ambiguity, conflict, and crisis in Greek higher education. Policy Studies Journal, 44(1), 59-82.

\section{Appendix}

\section{Appendix A}

\begin{tabular}{|c|c|c|c|}
\hline & & & Coding of Key Variables \\
\hline Variable & Characterization & Agency & Category \\
\hline Credibility & $\begin{array}{l}\text { Credible } \\
\text { Not Credible } \\
\text { Neutral/No Evidence }\end{array}$ & $\begin{array}{l}\text { FEMA, DHS, HUD, SBA, } \\
\text { Army Corps, NOAA, } \\
\text { TDEM, TDOT, GLO, } \\
\text { TASB, SEAGRANT, TEX- } \\
\text { AS A\&M, Rice, Other }\end{array}$ & $\begin{array}{l}\text { Recovery, Mitigation, } \\
\text { Preparedness, Response, } \\
\text { General Disaster Policy }\end{array}$ \\
\hline $\begin{array}{r}\text { Clarity of } \\
\text { Communication }\end{array}$ & $\begin{array}{l}\text { Clear, Unclear, } \\
\text { No Evidence }\end{array}$ & Federal or State & $\begin{array}{l}\text { Recovery, Mitigation, } \\
\text { Preparedness, Response, } \\
\text { General Disaster Policy }\end{array}$ \\
\hline $\begin{array}{r}\text { Clarity of Policy } \\
\text { Goals }\end{array}$ & $\begin{array}{l}\text { Clear, Unclear, } \\
\text { No Evidence }\end{array}$ & Federal or State & $\begin{array}{l}\text { Recovery, Mitigation, } \\
\text { Preparedness, Response, } \\
\text { General Disaster Policy }\end{array}$ \\
\hline Frustration & $\begin{array}{l}\text { Mention that } \\
\text { conveys the speaker } \\
\text { is frustrated }\end{array}$ & FEMA or TDEM & $\begin{array}{l}\text { Recovery, Mitigation, } \\
\text { Preparedness, Response, } \\
\text { General Disaster Policy }\end{array}$ \\
\hline $\begin{array}{r}\text { Instructions/ } \\
\text { messages }\end{array}$ & $\begin{array}{l}\text { Mention that } \\
\text { instructions or messages } \\
\text { from the sender are clear } \\
\text { or unclear }\end{array}$ & FEMA or TDEM & $\begin{array}{l}\text { Recovery, Mitigation, } \\
\text { Preparedness, Response, } \\
\text { General Disaster Policy }\end{array}$ \\
\hline $\begin{array}{r}\text { Ambiguity } \\
\text { about } \\
\text { the definition } \\
\text { of mitigation }\end{array}$ & $\begin{array}{l}\text { Mention that conveys } \\
\text { the speaker has a } \\
\text { definition of mitigation } \\
\text { which is not consistent } \\
\text { with FEMA's definition }\end{array}$ & FEMA & \\
\hline
\end{tabular}

